\title{
Globalisation and the financial sector
}

\begin{abstract}
Nowadays, when the international financial sector is experiencing significant changes, the finance industry is being discussed at a global level. The current crisis is the most devastating in recent economic history. Iconic Wall Street institutions, like Bear Stearns, Lehman Brothers and Merrill Lynch, have vanished; the world's largest mortgage insurers, Fannie Mae and Freddie Mac, have been nationalised; and the world's largest insurance company, AIG, with operations in 100 countries and with over 100000 employees, survives only by the grace of the US Treasury and to the tune of $\$ 85 \mathrm{bn}$. The current financial crisis in the US, that quickly spread to other parts of the world, has brought the debate on the polemics of financial globalisation to the fore. The purpose of this research reported in this article is to analyse the benefits and some of the challenges that the financial sector faces under the impact of globalisation and, on the basis of the findings, to put forward offers which will help emerging and developing countries benefit from globalisation.
\end{abstract}

Keywords: globalisation, financial sector, banks, financial markets

\section{Introduction}

Financial markets are not substantially stable. Before this crisis, many suggested that only emerging markets suffered from financial instability while, following the Nordic banking crises, some hoped that financial instability in advanced economies was just a transitional problem associated with financial deregulation. Now, we have learned that financial markets are not self-stabilising under certain conditions and that neither do they self-stabilise at any socially-acceptable cost. For example, 93 countries experienced 117 systemic and 51 lesser disruptions to their financial systems in the quarter-century before the latest global financial crisis [4].

What we need to do is to recognise that markets need rules, constraints and careful monitoring, so that market failures are less frequent and less costly. And that the rules, constraints and monitoring exercises need a macro-prudential approach - that is, one that tries to capture not only individual, but system-wide, risks.

It certainly appears to be the case that the emergence of new markets, such as highly liquid foreign exchange and derivative markets, has delivered essential financial transactions and contributed to the rapid expansion of global finance. However, the speculative uses of the new financial instruments in these markets have increased the diversity of the risks. Consequently, the availability of a wider range of financial instruments and deeper financial markets has enabled banks, non-bank financial institutions, institutional investors and companies better to manage their risks by using complex hedging strategies. 
This article seeks to analyse the benefits and some of the challenges faced by the financial sector under the impact of globalisation and is organised as follows: section 1 summarises the issues relating to the key characteristics of financial sector globalisation; section 2 considers the benefits and the challenges of the globalisation of the financial sector under the conditions of financial crisis; and finally section 3 explores the impact of globalisation on the development of the Latvian banking sector as a part of the global financial environment.

\section{Globalisation}

The focus of this article is the globalisation of banking and financial markets and its implications. The key characteristics of globalisation may be summarised as follows:

- borrowers, lenders and investors increasingly have global options with respect to sources of funding and the allocation of funds and savings

- the result is that the geographical domain of financial intermediation has widened and has become increasingly global. In its extreme form (but not yet achieved), the global financial system can be viewed as a set of financial markets, exchanges and institutions which trade in financial instruments and which channel world savings (wherever they are located) to investment wherever the risk-adjusted rate of return is considered to be greatest. In this way, financial institutions and markets intermediate in business between agents irrespective of their location or of that of the institution or market. The bulk of financial intermediation is still conducted within the domain of national financial systems, but this proportion is decreasing and, at the margin and especially for the corporate sector, global options have become increasingly available. In principle, this should raise efficiency in the allocation of financial resources in the global economy to the extent that savers, borrowers and institutions have wider options and are not restricted to domestic ones

- financial firms also locate outside their own country and conduct intermediation business for foreign local, domestic and international customers

- financial innovation (the creation of new financial instruments, markets and facilities) spreads quickly on a global basis

- shareholdings in both financial and industrial or commercial companies are becoming increasingly international in that, over time, the proportion of the shares of major banks and financial enterprises that is owned outside the country has been rising steadily

- various forms of arbitrage between financial markets and institutions take place on a global basis

- financial markets and institutions are not only in competition with each other but face increasing competition from outside their domestic countries. This is especially the case in the market for corporate and wholesale business but, to some limited extent, also in retail business

- shocks are transmitted internationally

- market discipline has been enhanced and the market in corporate control (the mergers and acquisitions market) has increasingly become international in the financial sector and again relates both to financial institutions and to markets: wit- 
ness the cross-border mergers and acquisitions in the banking sector and also in securities markets.

Globalisation has wider dimensions than those described above. However, the characteristics of globalisation that have been highlighted are those which are particularly relevant to the discussion that follows.

\section{Benefits or challenges of globalisation}

Financial globalisation has created clear efficiency benefits by intensifying competition within the key commercial banking market and by increasing the completeness of the financial market. Entry by foreign financial institutions using advanced credit risk assessment and portfolio management tools intensifies price competition and improves credit allocation by better matching price and non-price terms to the level of credit risk, thereby reducing the role of directed credit. FSFDI (foreign direct investment in the financial sector) has increased the completeness of markets as foreignowned financial institutions have introduced new financial products to emerging financial markets. The development of securities and derivatives markets provides alternatives to bank loans for channelling credit and liquidity in the local economy. Expanded consumer lending markets improve the economic welfare of households.

So far everything looks rather positive, but globalisation also implied changes, increased cross-border competition and pressures to adjust, all of which have provoked resistance and calls for protection, and not only in emerging markets. Throughout the world economy we can observe an increasing aversion to risk and to change.

The current financial crisis is obviously global, but would it help to keep within our own countries in order to minimise the impact of the financial crisis?

Unfortunately, the answer is negative, as we need international co-ordination. The perimeter of international co-ordination has widened. Just as risk management in individual firms does not add up to the stability of the financial markets so, too, macroeconomic and financial stability at the national level does not necessarily add up to global financial stability.

Home and host country supervisors need to co-ordinate their supervision of large, multinational institutions. Where foreign-owned institutions make up a large proportion of the financial sector of an emerging market country, the health and wellbeing of that country's financial system may depend greatly on the financial strength and managerial effectiveness of the parent organisation, as well as of the local subsidiary or branch.

Financial supervisors have carried out substantial work on improving co-ordination between home and host countries within the Basel Committee on Banking Supervision and the Joint Forum [1]. Supervisory information sharing is seen as key. The consolidated supervisor of the parent organisation needs a fairly complete and direct flow of information from the host country supervisors in order to develop a comprehensive picture of the organisation's financial condition and risk profile. In turn, host country supervisors would like to benefit from that comprehensive overview of the parent as they carry out their supervisory responsibilities. 
Progress has been made within the G-10 countries in facilitating information flows through memoranda of understanding, planning meetings between the supervisors of a global financial organisation and, in some cases, the joint examination of bank activities in host countries by host and home supervisors. Information-sharing activities with emerging market countries need to be widened and deepened where foreign parents are major participants in local markets. In particular, host country authorities want to receive information that is material to the operation of banking and financial markets within that country, recognising that some constraints exist, especially for public parent companies [5].

Co-ordination within such a framework, however, increases in difficulty as the number of relevant supervisors increases. The potential exists, but remains to be fully exploited, for disclosures by financial institutions to provide both the comprehensive overview of an individual financial firm's health and risk profile and the relevant country or industry segment detail which is sufficient to meet the needs of host country supervisors, depositors and counterparties. Country detail, in many cases, would remain at a level of aggregation sufficient to protect proprietary positions. One conceivable approach is the creation of an electronic financial statement and disclosure document that could use spreadsheet presentation tools for financial and risk information and which would allow greater drilling down into the details at lower levels of aggregation. Improved disclosure creates a presumption of openness, even when financial institutions are experiencing distress, as US banks found during the banking problems of the early 1990s.

Whether co-ordination is facilitated through supervisory information-sharing arrangements or enhanced public disclosure, or both, the greater role for foreign-owned, complex financial organisations diversified by geography and product segment creates new challenges for host country supervisors. Robust legal, accounting and regulatory frameworks in the host country facilitate supervisory co-ordination and information flows by reducing uncertainty about information, actions and impact. Adoption by emerging market countries of international principles and the standards promulgated by organisations such as the Basel Committee on Banking Supervision and the International Accounting Standards Board contribute to further improvements. Host country supervisors also need to understand the foreign legal, accounting and regulatory frameworks in order to assess the financial health of the parent and the obligations and constraints imposed by the home country on it $[8 ; 9]$.

The International Monetary Fund (IMF) has developed an index of compliance with the Basel Core Principles for Effective Banking Supervision which illustrates the opportunity for further improvements in emerging and developing economies. In addition, supervisors in both emerging markets and advanced countries face the need continually to enhance the financial and technical skills of examiners and supervisors.

Unfortunately, all these activities did not help avoid the consequences of the global crisis, and more countries have been joined in the international response to it. What remains to be done now?

The $\mathrm{G} 20$ has provided the political impetus for financial regulatory reform and policy co-operation. This push will make for more coherent macroeconomic and financial policies across countries. In particular, the new mutual assessment exercise that 
is underway is a promising signal of the commitment of G20 countries to co-operate on broader policies. The Financial Stability Board has a clear mandate to increase international co-ordination between policy-makers, financial regulators, supervisors and standard-setters. The Basel Process, which covers a wide range of co-operative efforts among banking supervisors, central bank financial market experts and deposit insurance and insurance supervisors, is part of the efforts co-ordinated by the Financial Stability Board. These new institutional arrangements have already started to produce significant results. One example is the formation of colleges of supervisors to co-ordinate the oversight of those firms that span national boundaries. New mutual assessment processes will ensure that internationally-agreed rules are enforced across all jurisdictions. To promote adherence to common standards, the Financial Stability Board is conducting two kinds of peer review: one on themes and another on particular economies. The Basel Committee is also overseeing peer reviews.

These are imperfect mechanisms, but they do provide a practical expression for the insight that global firms and global markets require global co-operation in regulation, supervision and macroeconomic policy.

\section{The Latvian banking sector}

Key indicators of the Latvian banking sector are included in Appendix 1, but the issue we want to explore here is whether the Latvian banking sector is part of the global financial system.

The simple answer is yes; however, our system has regional aspects - our banks are more Europeanised (see Charts 1 and 2). Latvian banks play an important role in attracting foreign investment. It is extremely important for Latvia to retain access to international capital markets to offset the external imbalance caused by the transitional period and to make efficient use of the technological and organisational possibilities related to foreign investment. A successful banking sector is, therefore, an essential precondition for restricting the risks of instability, and its prime responsibility is to set up a favourable investment climate that would attract foreign long-term investment. The role of banks in the attraction of foreign investment is confirmed in that, in 2009, $76.5 \%$ of institutional liabilities to monetary financial institutions was comprised of foreign banks' financing to their Latvian subsidiaries and branches. The share of foreign liabilities is less than in previous years (compared to $85.3 \%$ on 31 December 2005) but, taking into account the repayment of syndicated loans and a decrease in financing from foreign parent banks during the last two years, this level is still very high [6]. 
Chart 1 - Banking paid-up share capital in Latvia, broken down by countries, $2005(\%)[6]$

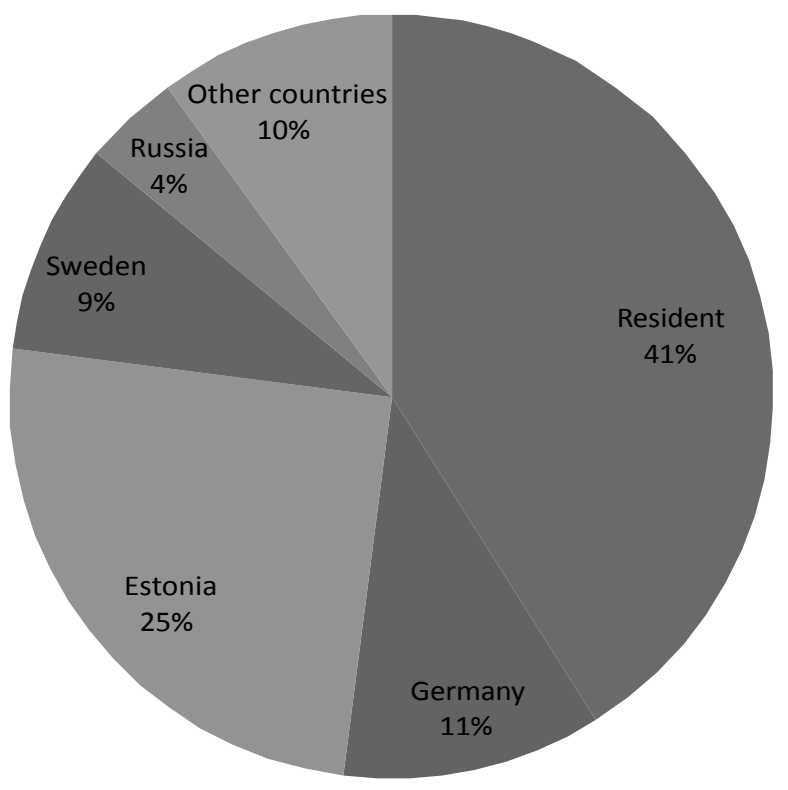

According to data from the Financial and Capital Market Commission, foreign shareholders owned $71.8 \%$ of the total paid-up share capital in Latvian banks at the end of 2009 (see Chart 2). This is lower than in previous years but, if we compare with 2005 (58.6\%) (see Chart 1), we would see a large increase. Foreign shareholders held over $50 \%$ of the paid-up share capital of ten banks [6]. 
Chart 2 - Banking paid-up share capital in Latvia, broken down by countries, $2009(\%)[6]$

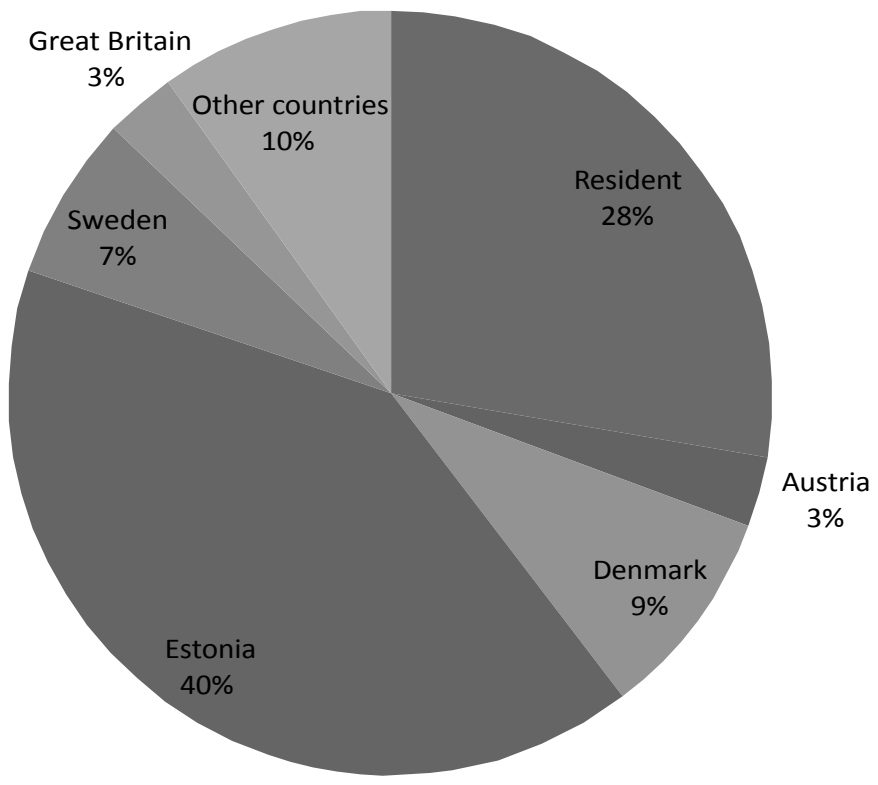

The information that has been highlighted indicates that the national banking sector is already a constituent part of the global financial environment.

The legislative framework for banking in Latvia meets the EU requirements in full and, in some areas, the requirements are even more rigorous. International Accounting Standards (IAS) have been fully introduced: banks' annual reports are prepared in accordance with IAS and audited by internationally recognised auditing firms. Practical supervision of the banking sector in Latvia is very tight and bank inspections are conducted more frequently than in EU member states.

But will it help achieve financial stability? To answer this question is a multi-faceted task and a lot of measures are on the table but, in this article, I will try to find the answer to one specific one, as capital is a central part of financial reform: 'Are the capital requirements in Latvia necessary and sufficient to achieve financial stability?'

In Latvia, regulations on the Calculation of Minimum Capital Requirements took effect on 11 May 2007 (transposing the requirements of directives 2006/48/EC and 2006/49/EC pursuant to the provisions of the Basel II Accord regarding minimum capital requirements), considerably affecting risk assessment and the risk management process in banks. Banks made use of the possibility of applying these Regulations which was provided for in the Credit Institutions Law of 1 January 2008, and submitted to the 
Commission the first reports for the first quarter of 2008 in accordance with the new Regulations.

Several new methods of risk measurement and assessment have been introduced along with the new Regulations, allowing for a more precise measuring of risk. The procedure for the calculation of the credit risk capital requirement has been completely changed; namely, banks may choose as the basis of the calculation either the standardised approach or the internal ratings based approach. Furthermore, in addition to the requirements for credit risk and market risk, the banks will also have to calculate the capital requirements for operational risk.

During the period of the new requirements (from the first quarter of 2008 to the end of 2009), the total amount of banking capital requirements decreased by 22.6 million lats, or $2 \%$. In 2009 , the total amount of banking capital requirements decreased by 81.6 million lats, or $6.8 \%$. That is, following a decrease in the loan portfolio, the capital requirements for credit risk shrank the most - by 63.5 million lats, or 5.9\%. By endDecember 2009, the total amount of banking capital requirements made up 1126.9 million lats, of which the greater share, or $90.2 \%$, was the capital requirement for the credit risks inherent in the banking book; $8.1 \%$-the capital requirement for operational risk; and $1.7 \%$ - the capital requirement for position, foreign currency and commodity risks (see Chart 3) [6].

\section{Chart 3 - Breakdown of capital adequacy requirements from 2008-2009 in Latvia (in million LVL) [6]}

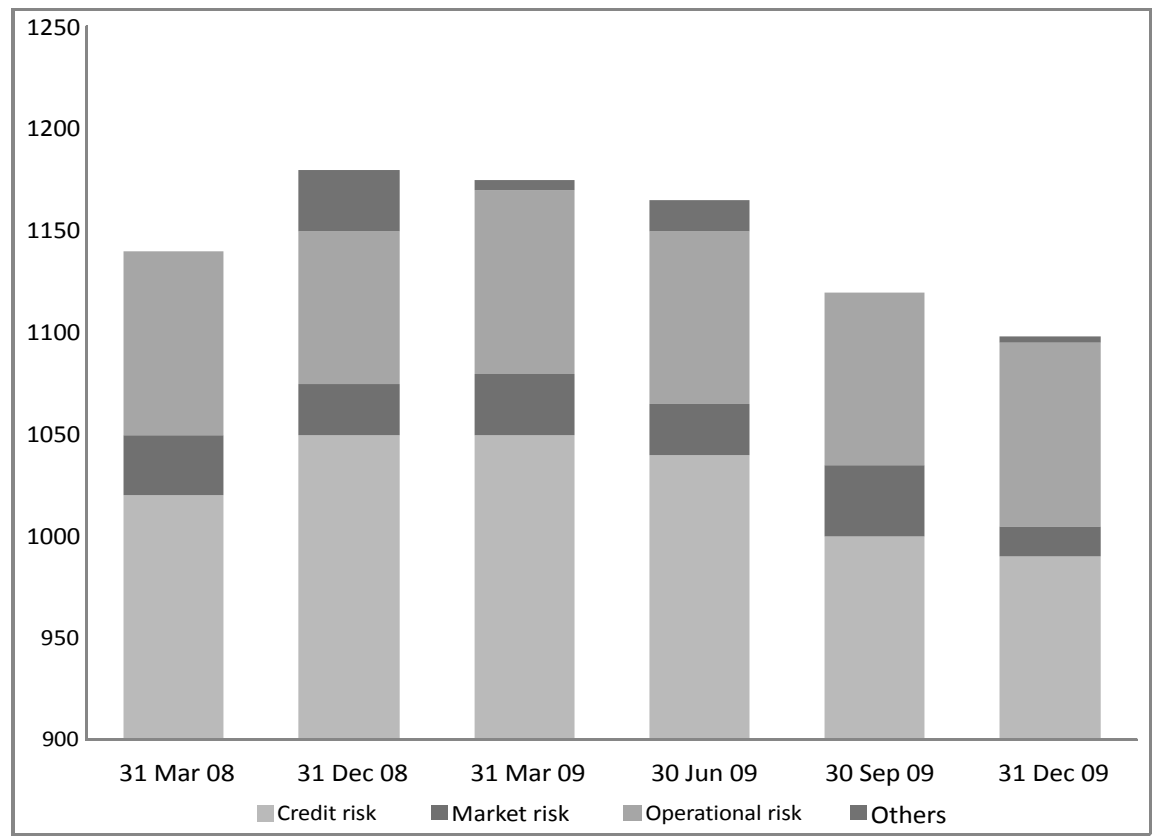


Following the ongoing deterioration in the quality of banking assets, and considering the necessity for notable additional provisioning for loan impairment, the banks attempted to strengthen their capital base in 2009 - 13 Latvian banks increased their capital by about one billion lats in total, of which share capital was increased by 728 million lats, subordinated capital by 222 million lats and reserve capital by 48 million lats. Subsequent to an increase in banking equity of $14.7 \%$, and a decrease in the amount of bank risk-weighted assets of $6.8 \%$ in 2009 , the capital adequacy ratio of the banking sector grew and, at end-December, it totalled $14.6 \%$ (compared to $10.1 \%$ at end-2005) (see Chart 4) [6].

\section{Chart 4 - Capital adequacy ratio from 2005-2009 in Latvia (\%) [6]}

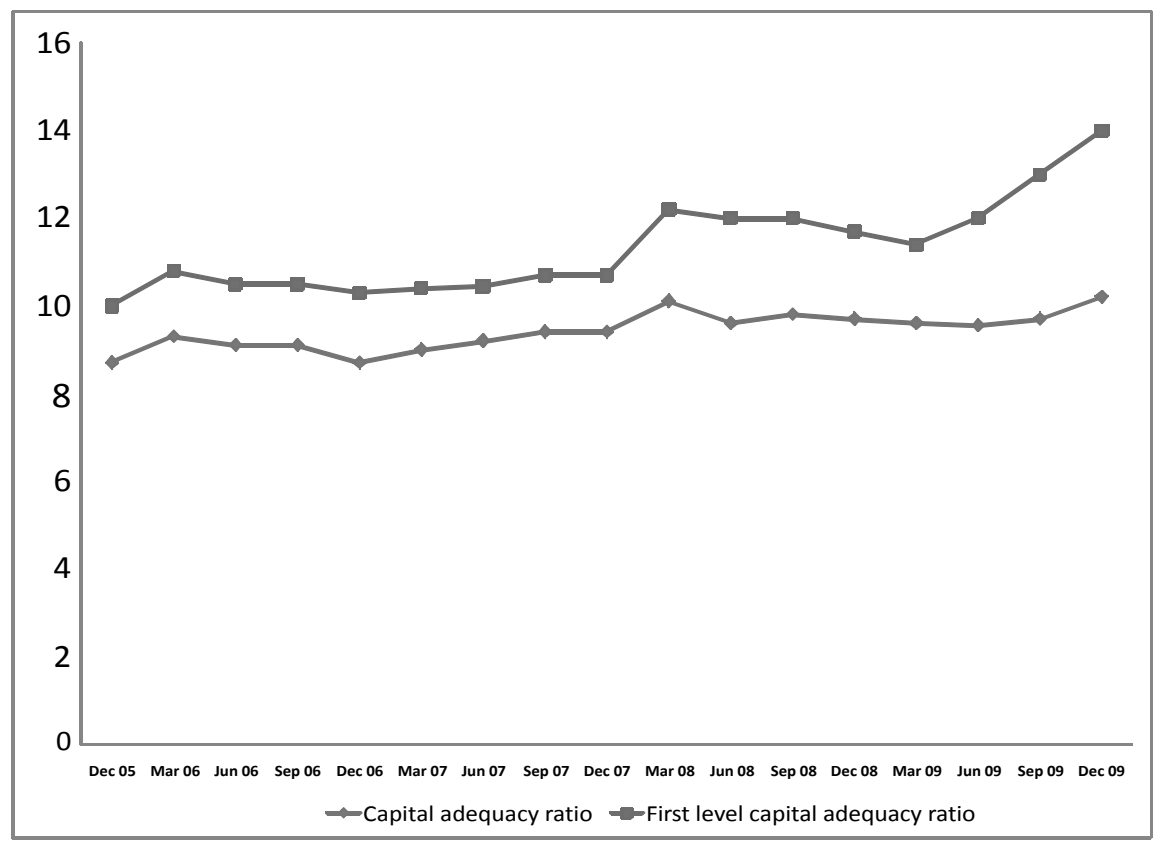

By the end of 2009, a capital adequacy ratio below $10 \%$ was the case for only one bank, with a share of the banking market of only $4 \%$, compared to the end-2005 position when this was the case for seven banks which had a share of the market of over $70 \%$ (see Table 1) [6]. 
Table 1 - Bank groups in Latvia broken down by capital adequacy ratio in 2005 and $2009[6]$

\begin{tabular}{|l|c|c|c|c|}
\hline \multirow{2}{*}{$\begin{array}{l}\text { Capital } \\
\text { adequacy } \\
\text { ratio } \\
(\%)\end{array}$} & $\begin{array}{c}\text { Number of } \\
\text { banks }\end{array}$ & $\begin{array}{c}\text { Banking market } \\
\text { share } \\
\text { (\% of total banking } \\
\text { assets) }\end{array}$ & $\begin{array}{c}\text { Number of } \\
\text { banks }\end{array}$ & $\begin{array}{c}\text { Banking market } \\
\text { share } \\
\text { (\% of total banking } \\
\text { assets) }\end{array}$ \\
\hline below 10 & 7 & 74.4 & 1 & 4.0 \\
\hline $10-15$ & 7 & 18.3 & 9 & 38.0 \\
\hline $15-20$ & 3 & 5.5 & 7 & 55.9 \\
\hline above 20 & 5 & 1.9 & 4 & 2.1 \\
\hline
\end{tabular}

Overall, we can see a drastic increase in the capital adequacy ratio for the majority of banks compared to 2005. Is this increase in capital reserves sufficient to achieve financial stability? The answer is both 'yes' and 'no': capital requirements are necessary, but they are not sufficient. Indeed, I would argue that regulation was only part of the problem and it is only part of the answer. Capital is not enough; regulation is not enough. Capital reserves (buffers) and provisions need to be built up in good times so that they can be used in bad times, thus reducing the risk of spill-over from the financial sector to the real economy. Lessons have been drawn by the Basel Committee on Banking Supervision concerning the need to improve the quality of capital, i.e. both to raise the level of capital and to improve the framework's capture of risk, especially as regards the trading book [7].

One of the most fundamental improvements introduced by the Basel Committee in its reform package is the macro-prudential focus on addressing both system-wide risks and the pro-cyclical amplification of risks over time [3]. I would venture further the requirement, as just stated, to build up capital buffers even higher in good times so that more can be taken from them in bad times.

It may well be true that, in the period after the restoration of independence, the Latvian economy has not had a chance to experience the full cycle of economic activity and that, as a result, domestic bankers do not have enough experience in this area. Luckily, however, most of the largest banks in Latvia are owned by foreign shareholders that do have the requisite expertise and experience. They are also best positioned to provide the necessary incentives for the domestic management of commercial banks in Latvia. The foreign shareholders of the largest Latvian or, indeed, pan-Baltic banks must put higher emphasis on risk management and pay greater consideration to the sustainability issues involved in developing business strategies, as opposed to shortterm growth issues, for their Baltic branches. For our banking system, which is relatively young, this could be the best way of benefiting from more mature markets where banking experience and expertise have been accumulated over several hundreds of years. 


\section{Conclusions}

1. The main changes brought by globalisation are these: the trends towards intensive cross-border financial and payment flows; greater risk-sharing internationally through a broader array of financial instruments; an increasing share of crossborder holdings of assets; and an increasing international profile for financial markets, market players and institutions.

2. The gains from globalisation are:

- intensified competition within the key commercial banking market and increased financial market completeness

- introduction of new financial products

- establishment of alternatives to bank loans via the development of securities and derivatives markets

- improved household economic welfare

- intensified price competition and improved credit allocation by a better matching of price and non-price terms to the level of credit risk, thereby reducing the role of directed credit

- a contribution towards financial stability in emerging markets by the integration of local financial institutions into larger, global foreign institutions

- provision of access to global capital markets through the parent's more relaxed equity and funding constraints

- the opportunity to restructure or reposition a weakly-performing financial institution or business unit.

3. One of the main challenges of financial sector globalisation is the need for home and host country supervisors to co-ordinate their supervision of large, multinational institutions.

4. Financial supervisors have carried out substantial work on improving co-ordination between home and host countries in the Basel Committee on Banking Supervision and the Joint Forum. Unfortunately, all these activities have not helped avoid the consequences of the global crisis, although more countries have joined in the international response to the crisis. What we need to do now is to develop a macroprudential approach towards international co-ordination - something that has already been started by G20.

5. Latvian banks have a significant share of foreign assets and liabilities, indicating that the national banking sector is already a constituent part of the global financial environment. At the end of 2009 , foreign shareholders owned $71.8 \%$ of the total paid-up share capital of Latvian banks and held over $50 \%$ of the paid-up share capital of ten banks.

6. The legislative framework for banking in Latvia meets the EU requirements in full and, in some areas, the requirements are even more rigorous. Practical supervision of the banking sector in Latvia is very tight and bank inspections are conducted more frequently than in EU member states.

7. Information-sharing activities in conjunction with emerging and developing market countries need to be widened and deepened where foreign parents are major participants in local markets. Progress has been made within the G20 countries in facilitating information flows through memoranda of understanding, planning 
meetings between supervisors of global financial organisations and, in some cases, the joint examination of banking activities in host countries by host and home supervisors.

8. One conceivable approach of the co-ordination of regulatory frameworks, when the number of relevant supervisors is high, is the creation of an electronic financial statement and disclosure document that could use spreadsheet presentation tools for financial and risk information and which would allow a greater level of drilling down into the details at lower levels of aggregation.

9. One of the most fundamental improvements introduced by the Basel Committee in its reform package is the macro-prudential focus on addressing both systemwide risks and the pro-cyclical amplification of risks over time. I would add the need for a greater building up of capital buffers in good times so that more can be taken from them in bad ones.

10. The foreign shareholders of the largest Latvian or, indeed, pan-Baltic banks must put more emphasis on risk management and pay greater consideration to the sustainability issues inherent in developing business strategies for their Baltic branches.

\section{References}

Alfaro, R. and M. Drehmann (2009) 'Macro stress tests and crises: what can we learn?' BIS Quarterly Review December: 29-41.

Bank of Latvia: annual reports, monetary reviews and monetary bulletins.

Basel Committee on Banking Supervision (2009) Strengthening the resilience of the banking sector - consultative document December, www.bis.org.

Caruana, J (2010) Financial stability: 10 questions and about seven answers 50th Anniversary Symposium of the Reserve Bank of Australia, Sydney, 9 February, www.bis.org.

Crockett, A (2004) Interview reported in SUERF Newsletter SUERF: Vienna, December, p. 3.

Financial and Capital Market Commission: quarterly and monthly reports from 2005 to 2009 .

Frankel, A (2009) The risk of relying on reputational capital: a case study of the 2007 failure of New Century Financial BIS Working Papers No. 294, December.

Franks, J (2006) 'The right conditions for trust between businesses, Mastering Financial Management' Financial Times 16 June, p. 6.

Maier, S (2006) 'Structural factors behind the German banking system's weak profitability' UniCredit Banking and Financial Monitor 2, July, p. 30. 
Appendix 1 - Key indicators of the Latvian banking sector [2]

\begin{tabular}{|c|c|c|c|c|}
\hline & $\begin{array}{c}\text { Reporting } \\
\text { period }\end{array}$ & Data & $\begin{array}{c}\text { Data of } \\
\text { previous } \\
\text { period }\end{array}$ & $\begin{array}{l}\text { Data of same } \\
\text { period of } \\
\text { prior year }\end{array}$ \\
\hline $\begin{array}{l}\text { Total assets* (at end of period; in } \\
\text { millions of lats) }\end{array}$ & 2009 IX & 20337.2 & 20411.0 & 22125.9 \\
\hline $\begin{array}{l}\text { Total assets (at end of period; } \\
\text { compared with corresponding } \\
\text { period of previous year; \%) }\end{array}$ & 2009 IX & -8.1 & -8.1 & 12.5 \\
\hline Loans to residents (millions of lats) & 2009 IX & 13880.8 & 13921.5 & 14594.0 \\
\hline Loans in lats & 2009 IX & 1216.2 & 1279.5 & 1744.7 \\
\hline Loans in foreign currencies & 2009 IX & 12664.5 & 12642.1 & 12849.3 \\
\hline $\begin{array}{l}\text { Growth in loans to residents } \\
\text { (compared with corresponding } \\
\text { period of previous year; \%) }\end{array}$ & 2009 IX & -4.9 & -3.7 & 17.6 \\
\hline $\begin{array}{l}\text { Loans overdue for over } 90 \text { days (\% } \\
\text { of total loans) }\end{array}$ & $\begin{array}{l}2009 \text { VII- } \\
\text { IX }\end{array}$ & 14.5 & 12.0 & 2.5 \\
\hline $\begin{array}{l}\text { Deposits from residents (in millions } \\
\text { of lats) }\end{array}$ & 2009 IX & 4871.9 & 4914.1 & 5271.9 \\
\hline Deposits in lats & 2009 IX & 2068.5 & 2075.8 & 2765.6 \\
\hline Deposits in foreign currencies & 2009 IX & 2803.4 & 2838.3 & 2506.3 \\
\hline $\begin{array}{l}\text { Capital and reserves (in millions of } \\
\text { lats) }\end{array}$ & 2009 IX & 1549.7 & 1615.8 & 1873.7 \\
\hline $\begin{array}{l}\text { Retained earnings for the reporting } \\
\text { year (millions of lats) }\end{array}$ & 2009 IX & -573.5 & -450.6 & 213.4 \\
\hline $\begin{array}{l}\text { Broad money M3 (at end of period; } \\
\text { millions of lats) }\end{array}$ & 2009 IX & 5614.4 & 5654.7 & 6380.7 \\
\hline $\begin{array}{l}\text { Broad money M3 (compared with } \\
\text { corresponding period of previous } \\
\text { year; \%) }\end{array}$ & 2009 IX & -12.0 & -13.2 & 5.6 \\
\hline
\end{tabular}

